Исидора Церовац

Универзитет у Београду

Филолошки факултет
378-057.175(=161.1:497.15)"1925/1945"

314.743(=161.1)(497.15)"1925/1945"

https://doi.org/10.18485/melissa.2017.16.2.ch9

\title{
ПОЗНАТИ РУСКИ ЕМИГРАНТИ У БАњАЛУЦИ (1925-1945)
}

\section{Сажетак}

Овај рад се бави истраживањем живота и рада познатих руских емиграната, који су боравили и радили у Бањалуци у оквирном временском периоду од 1925. године до 1945. године. У раду смо се ограничили на неколико струка, те укључили архитекте, директоре важних емигрантских удружења, лекаре, учитеље и професоре, те режисере и глумце.

Истраживање је пре свега рађено на основу архивске грађе која се чува у Архиву Републике Српске, у Бањалуци. Већина материјала је електронског типа, те за многа документа немамо тачну класификацију по којој се чувају у архиву. Темом руске емиграције у Босни и Херцеговини се готово нико није бавио. Конкретно о животу и делању руске заједнице у Бањалуци писао је само Зоран Мачкић, који је објавио неколико текстова и чланка у новинама и „Гласнику Удружења архивских радника Републике Српске“.

Анализом архивске грађе и малобројних текстова аутор рада је покушао да приближи слику живота и рада само неких од најистакнутијих руских емиграната у некадашњем центру Врбаске бановине, фокусирајући се на судбину емиграната којима је она била пребивалиште, рад Руске колоније и Руске матице као основних организација, као и на допринос руске интелигенције, тачније архитеката, лекара, уметника и професора.

Кључне речи: руска емиграција у Бањалуци, архивска грађа, Руска колонија, Руска матица, руска интелигенција, архитекте, лекари, учитељи и професори, глумци и режисери.

\section{1. Увод}

Победом Октобарскереволуције 1917. године Русијује напустило преко два милиона емиграната који су се размилили широм света. 
Настанили су се у низу европских и прекоморских земаља. На оносву споразума Пашић-Врангел ${ }^{1}$, Краљевина СХС пристала је да прими око 50.000 војника из Врангелове армије ${ }^{2}$. Иако је званично тај број био много већи, и међу емигрантима нису била само војна лица. Емигранти су размештени по целој тадашњој територији Југославије. Центри емиграције били су у данашњој Србији Београд, у Хрватској Загреб, а у Босни и Херцеговини Сарајево. Бањалука је, поносно, такође била један од мањих центара, иако је и сама тада била слабо развијена.

У Бањалуци је према попису становништва Краљевине СХС из 1921. године било 485 руских емиграната ${ }^{3}$. Током 30-их година их је било много више, међутим нисмо успели наћи статистичке податке из тог периода. Велики број стручњака међу њима се успео снаћи и искористити своје таленте стечене у Русији. Мали град на Врбасу је имао срећу да угости нека од највећих глумачких и режисерских имена, да њихову децу школују учени руски професори и наставници, да здравство подигну на виши ниво руски лекари, а да њене улице красе здања неких од најбољих архитеката.

Овим радом смо покушали да на основу архивске грађе систематизујемо поједине биографије познатих руских емиграната који су боравили у Бањалуци. Иако је било доста емиграната професионало различито оријентисаних, у раду смо се ограничили на неколико струка, те укључили директоре важних емигрантских удружења, лекаре, учитеље и професоре, те режисере и глумце. На тај начин су у први план дошли друштвени, културни и образовни аспекти о којима се до сада није много писало. Број руских емиграната у односу на укупан број становника није био велик, као што видимо из наведених статистичких података, али су и у тако малом броју многи од њих учествовали у научном, културном, уметничком и друштвеном животу града Бањалуке.

1 Петар Николајевич Врангел (рус. Пётр Николаевич Врангель) (1878 -1928) био је барон, генерал, активни учесник и вођа антибољшевичког покрета у Руском грађанском рату после Октобарске револуције 1917. године. Сахрањен је Београду, у руској цркви Свете Тројице на Ташмајдану, поред цркве светог Марка.

2 Тома Миленковић. Момчило Павловић. Белоемиграција у Југославији. Београд. 2006. стр. 29

3 Алексеј Борисович Арсењев.Русская эмиграция в Боснии и Герцеговине.Ежегодник 2011 Дома русского зарубежья им. А.Солженицына. Москва. 2011 


\section{2. Руске архитекте}

Почетак градње у Бањалуци (1925) се донекле поклапа са првим таласом руских емиграната (1920), којима је тај град често био транзитни за прелазак из Београда у Загреб, а даље у Европу. У Бањалуци је после рата владала стагнација која се одразила и на урбанистички развој града и на саме могућности улагања у капиталне инвестиције. Међутим, са демографским растом јавља се и потреба за изградњом станова и других објеката. Свакако је најзначајнији моменат за Бањалуку изградња Бановинске палате и Банског двора - пројекти на којима су радили познати руски архитекти и инжењери. Ови објекти су заједно са Саборном црквом, чија је градња почела 1925. године, формирали дефинисани симетрични трг који и данас маркира град ${ }^{4}$. Аутори многих пројеката били су једни од најцењенијих архитеката као што су Александар Медведев, Виктор Зелински, Никола Федоров и други. Управо кроз њихове биографије смо се потрудили представити како се Бањалука захваљујући њиховим иновативним идејама развијала. Многе од грађевина се могу и данас видети у Бањалуци, међутим мали број је оних који знају чијих идеја оне представљају реализацију 5 .

Александар Медведев рођен је 12. марта 1900. године у Мелитопољу (Русија). Након што је завршио средње образовање у Мелитопољу намеравао је да студира архитектуру, али због револуционарних дешавања је одустао од студија и заједно са пријатељима и професорима из училишта придружио се добровољцима. Желео је да пређе у Париз и тамо настави своје школовање, али емигрантски пут га је одвео до Турске и Бугарске, где је преживљавао бавећи се физичким радом. Након боравка у Софији, решио је да се ипак упути у Француску. Међутим, пролазећи кроз Краљевину СХС у Београду се сусреће са својим руским пријатељима и решава да остане у том граду, који је пружио уточиште многим емигрантима. Уписао се на Архитектонски одсек Техничког факултета, где је током студија зарађивао радећи у многим пројектним бироима. Управо се на универзитету упознао са својом будућом женом Ксенијом, која је била на студијама грађевине на Техничком факултету у Београду. Она је убрзо прешла на архитектуру и заједно са Александром наставила студије.

4 Синиша Цвијић. Модерна стамбена архитектура Бањалука 1929-1941. Београд.2014. стр. 25

5 Исидора Церовац. Руска емиграција у Бањалуци. Београд. 2016. (мастер рад) 
Ксенија Петровна Белавенец била је ћерка поморског официра Петра Ивановича Белавенца, из познате дворске породице морепловаца и научника, а мајка Љубов Гавриловна пијанисткиња, из богате украјинске земљопоседничке дворске породице. Ксенију Медведев, крстила је руска царица Марија Фјодоровна, мајка Николаја II Романова. Ксенија и Александар су се венчали 1927. године у храму Свете тројице у Београду. А. И. Медведев завршио је архитектуру 1929. године и постао један од најзначајнијих представника стила модерна, авангардног правца између два светска рата. Највећи број његових пројеката реализованјеуНишугдејеиживео са супругомод 1935. године до 1984. године. Млади брачни пар дошао је у Бањалуку 1930. године на позив бана Врбаске бановине Светислава Тисе Милосављевића. Александар Медведев учествовао је на конкурсу за нове заграде Банске управе. Жири му је дао високу оцену за његов пројекат у стилу касног академизма, али је дисквалификован, јер је здање које је Александар Медведев замислио премашило величину објекта која је била прописана у конкурсу. У име предузетника Косте Шијачког, ипак му је додељено да води радове на новом објекту. ${ }^{6}$ Паралелно са изградњом Банског двора, Александар Медведев је полагао државни испит за добијање грађевинске лиценце. Пројектовао је и градио много кућа, школа и приватних вила у Бањалуци, као и другим градовима Врбаске бановине. Међутим, документацију у виду слика, скица или цртежа нисмо успели да пронађемо за већину његових грађевина у Бањалуци. На овим пројектима се први пут опробао у новом, њему савременом уметничком стилу. Ксенији, његовој жени, је са друге стране бан поверио пројекат изградње ловачког дома за краља Александра. Пројектовала је интересантан објекат, у стилу брвнаре са елементима руско-украјинског националног стила. Како је краљ Александар убијен у атентату 9. октобра, пројекат Ксеније Медведев није био никада реализован. Ксенија Медведев је поклонила бањалучком Заводу за заштиту споменика културе обимну и много значајну документацију о изградњи Банске палате и Дворских двора. Документа садрже детаљне информације о изворима финансирања, ценама грађевинских материјала, фирмама

6 Зоран Мачкић. Записи из архива:Изградња палата Банске управе и Банских двора: Двије несуђене скице. http://banskidvor.org/zapisi-iz-arhiva-izgradnja-palata-banskeuprave-i-banskih-dvora-dvije-nesudjene-skice/ (26.11.2016.) 
које су биле у улози добављача. У овом раду смо одлучили искључити те податке, како бисмо више пажње дали културолошком аспекту.

Григориј Иванович Самојлов (1904-1989) родио се у Донској области 1904. године, где се школовао у Донском кадетском корпусу Александра III. 3бог дешавања у грађанском рату заједно са оцем је емигрирао у Краљевину СXС, где је и наставио своје образовање у Донском корпусу. Након тога је завршио архитектонски одсек на Београдском Техничком факултету. Праксу је стекао у бироу архитекте Александра Ђорђевића, после чега је био асистент на Катедри за византијску и стару српску архитектуру Техничког факултета. Остварења великог броја пројеката, њих скоро 180, на којима је радио у периоду од 1921. године, па све до смрти 1989, могу се и данас видети у многим градовима бивше Југославије. Његов рад у Београду и Нишу је многима познат, али о његовом боравку и делању у Бањалуци се мало зна. Самојлов је пројектовао иконостас и ентеријер Храма Свете Тројице у Бањалуци. Поред њега на изради ентеријера радио је Јован Бијелић са групом (〉Облик» којој су припадали Вељко Станојевић, Петар Сухачов (руски емигрант, академски сликар) и Светислав Страла. Фреске и иконе израдили су Сухачов и Јарослав Кратина. Нацрт иконостаса, полијелеј и столарију урадио је Григорије Самојлов. Радови на ентеријеру трајали судо 1939. године, а архитекта Григорије Самојлов записао је и своја сећања о пројектовању и реализацији ентеријера Православне цркве у Бањалуци. Григорије Самојлов подсећа да је половином 1936. године расписан конкурс за идејно решење иконостаса за бањалучки храм. „Из (Политике) од 14. 09. 1936. године дознао сам о додељеној ми првој награди, а кроз кратко време стигао је и позив од Црквене општине да дођем у Бању Луку ради договора о свим потребним радовима и склапању уговора» ${ }^{7}$, забележио је Григорије Самојлов. Након што је видео храм неколико лепих розета на фасадама цркве дало му је идеју да то буде везни елемент између екстеријера и ентеријера (округли медаљони са апостолима на средњем делу иконостаса), како је касније говорио. ()Уместо уобичајеног покривања свих површина зидова великом количином релативно ситних композиција, предвидео сам места за

7 подаци преузези са интернет странице Саборног Храма Христа Спаситеља у Бањалуци у одељку „Историјат храма“, стр. 4. http://hhsbl.org/index.php?option=com_content\&vi ew $=$ article\&id=5\&ltemid=5\&lang=sr\&limitstart $=3$ (04.12.2015.) 
мањи број великих композиција, међусобно издвојеним једнобојном површином и орнаментираним луковима и пиластрима, да би се добила монументална мирноћа и јединство простора ${ }^{8}$, открио је даље Григорије Самојлов. Сматрао је срећном околношћу што су радови поверени "једном од најталентованијих уметника српског сликарства тог времена - Јовану Бијелићу". Самојлов је "имајући на уму да се боје рађају са појавом светлости и нестају са њеним гашењем" ${ }^{\prime \prime}$ обратио посебну пажњу на распоред и врсту светлећих тела, како видљивих тако и сакривених рефлектора, а такође и на редослед њиховог паљења и гашења, чиме су постизани жељени ликовни ефекти. Нажалост, током Другог светског рата Храм Свете Тројице био је срушен, и тек након скоро седам деценија храм је обновљен. У Архиви Босанске Крајине пронађене су скице бившег пројекта Саборног храма, на основу којих је урађена пројектна документација за обнову и изградњу новог храма. Чак је и иконостас на којем је радио Самојлов, урађен према његовим скицама.

Никола Федоров рођен је у Санкт Петербургу у Русији, а умро је1940. године у Бањалуци. Сахрањен је у Земуну у Београду. Служио је као активни официр у руској војсци и са њеним повлачењем стигао је у Србију где је у Београду 1928. године дипломирао на Архитектонском одсеку Техничког факултета. Државни технички испит положио 1931. при Министарству грађевина. У Бањалуку је дошао 1930. године, где је радио као приправник у Техничком одељењу Краљевске банске управе. Радио је на више значајних пројеката у духу модерне архитектуре, међу којима су сигурно најзначајнији доградња Хигијенског завода и Хируршки павиљон Бановинске болнице. „Зграда Хигијенског завода има разуђену основу са израженом волуметријом, док је Хируршки павиљон потпуно функционалистички пројектован са безорнаменталном фасадом. ${ }^{10}$ Потпуно ауторско дело Николе Федорова представља кућа директора Ниже пољопривредне школе из

8 подаци преузези са интернет странице Саборног Храма Христа Спаситеља у Бањалуци у одељку „Историјат храма“, стр. 4. ttp://hhsbl.org/index.php?option=com_content\&vie $\mathrm{w}=$ article\&id $=5 \&$ Itemid $=5$ \&lang $=$ sr\&limitstart $=3$ (04.12.2015.)

9 подаци преузеtи са интернет странице Саборног Храма Христа Спаситеља у Бањалуци у одељку „Историјат храма“, стр. 4. http://hhsbl.org/index.php?option=com_content\&vi ew $=$ article\&id $=5 \&$ Itemid $=5$ \&lang $=$ sr\&limitstart $=3$ (04.12.2015.) 
1936. године у улици Кнеза Милоша. Унутрашњост куће пројектовао је пре свега врло функционално. Кућа се састојала од јавног дела у приземљу, приватног дела на спрату и опслужујућег дела који је заузимао простор у приземљу и подруму. Оно што у изградњи ове куће представља извесну иновацију, тачније напредак у односу на дотадашњу градњу је употреба армиране ситноребрасте таванице за конструкцију таванице изнад подрума и за раван кров. Током 1930. разрадио је планове за изградњу Банских двора. Заједно са Бранком Јовановићем био је члан Комисије за пријем радова вајара Ђорђа Јовановића - шест скулптура за фасаду Банског двора 1931. године. Актом KBUVB, Технички одељак, број 9096/31 од 5. маја 1931. године постављен је за надзорног инспектора приликом градње Банских двора.

„9. о.м. умро је у Бањалуци инж. Федоров Никола архитекта Банске управе који је као вредан и способан чиновник заузимао у Техничком оделењу врло видно место. Као млад инжењер пре 10 година долази г. Федоров у Бањалуку баш у часу, када се по једном програму изводе- нарочито на техничком пољу, многобројни радови, у које уноси он необичну вољу, истрајност и солидно знање. За овакав плодоносни и савестан рад био је одликован на предлог својих старешина, који су ценили и признавали његове стручне и чиновничке способности. Г. Федоров спада у ону генерацију, која је у прошлом светском рату преживела највећа страдања по ратиштима, и затим лутања и тегобе по непознатим и туђим земљама Европе.... Овај човек са прохујалом младошћу и идеалима у ратним бурама, која је оставила дубоког трага на његово здравље, сам се издржавао и школовао без ичије помоћи, упорно се и даље борећи кроз живот...."11

Виктор Зелински такође је један од архитеката који је оставио трага у Бањалуци. Забележено је да је након доласка из Русије после Октобарске револуције пројектовао цркву са романичким елементима у Цриквеници, чија је изградња почела 1928. године. Као већина емиграната мењао је место рада, па је у управи Нишке бање радио од 1934. године, а одоктобра 1938. године радиојеуВарварину. УБањалуку се доселио 31. маја 1939. где је постављен за вршиоца дужности шефа техничког одела Хигијенског завода. Од 22. октобра до 23. децембра 1941. био је привремено у Загребу, након чега се вратио у Бањалуку.

11 Бранко Јовановић.In memoriam. Врбаске новине. Бања Лука. XI, 1714, 12. мај 1940, стр. 2. 
Разрешен је дужности 5. октобра 1943. Наредбом Министарства промета и јавних радова, Сл. 3045/45 од 24. фебруара 1945. године, отпуштен је из државне службе, а разрешен је 30. септембра 1945. Један од непотпуно остварених пројеката Виктора Зелинског била је Бурдина кућа. ${ }^{12}$ Артур Бурда био је познати привредник и почасни конзул Пољске у Краљевини Југославији. Његова кућа представља јединствено остварење архитектуре вањског и унутрашњег простора. Иако су куће које су тада грађење у Бањалуци углавном одисале духом модернизма, ова кућа поседује карактеристике традиционалне босанске архитектуре када говоримо о вањском изгледу. Зелински је радећи на овом пројекту много размишљао и самом месту где је кућа била грађена и потпуности га окренуо у своју корист. „Кућа се налази на пространој парцели неправилног облика која је у паду према истоку. Карактеристике терена су вешто искоришћене и кућа је постављена тако да собе и просторије за боравак гледају према истоку, односно према граду.“13 Делу куће који није изведен припада сутерен у којем је планиран трем са масивним стубовима и луковима. Бурдина кућа је изграђена у „масивном систему од опеке са дрвеним гредама као међуспратном конструкцијом које се на споју са зидом ослањају на армиранобетонски вијенац.“ ${ }^{14}$

Зграда Хипотекарне банке изграђена је 1936. године на углу данашње улице Бана Милосављевића и Бана Др Т. Лазаревића. Као већина здања пројектованихтада, тако се и ово креће између модерног стила и стила Арт Деко. Сама фасада је наглашена монументалним дорским стубовима, а парапети испод прозора су декорисани рељефима. ${ }^{15}$ Владимир Павлович Загородњук био је аутор рељефа на парапетима, од којих се данас може видети само један на самом улазу. Рељефи су тешко оштећени у земљотресу 1969. године. Главни улаз био је украшен 24. априла 1937. године са две скулптуре Владимира Павловича. Бронзане фигуре „Трговина» и «Домаћинство» које су биле тешке око 600 килограма свака, рађене су у ливници Властимира

12 Синиша Цвијић. Модерна стамбена архитектура Бањалука 1929-1941. Београд.2014. стр. 40

13 Синиша Цвијић. Модерна стамбена архитектура Бањалука 1929-1941. Београд.2014. стр. 40

14 Синиша Цвијић. Модерна стамбена архитектура Бањалука 1929-1941. Београд.2014. стр. 39,40

15 Синиша Цвијић. Модерна стамбена архитектура Бањалука 1929-1941. Београд.2014. стр. 30 
Ђорђевића у Београду. Десно од улаза постављена је статуа Крајишника «Трговина» у народној ношњи са штапом и кантаром у рукама, те са врећом изобиља поред себе. Лево од улаза се налази Крајишкиња "Домаћинство», такође у народној ношњи са српом у руци и снопом жита поред ње, који представља благостање, сједињење и друштвену слогу. Загородњук је после Октобарске револуције и грађанског рата у Русији емигрирао у Краљевину СХC ${ }^{16}$. Једно време радио је као наставник цртања у руској школи у Панчеву, а од 1921. године је био сценограф и костимограф у београдском Народном позоришту. До избијања Другог светског рата постао је сценограф 19 значајних драма и 12 опера, а након рата дао је значајан допринос у обнављању Народног позоришта. За сценографију Војновићеве “Смрти мајке Југовића" на изложби у Паризу му је 1924. додељена златна медаља. Свој атеље је отворио 1927. године када се интензивно почео бавити скулпторским радовима, декорисању јавних објеката и изради споменика у Београду, Ваљеву, Опленцу, Бељу. Одселио се са породицом у Аустралију 1950. године. Умро је 1976. у Сиднеју. Своје позоришне скице је завештао Народном позоришту у Београду. Слике хипотекарне банке у Бањалуци је сачувао пријатељ Загорудњака Виталиј Рибкин, које је Татјана Рибкин послала Архиву Републике Српске. ${ }^{17}$

\section{3. Директори Руске колоније и Руске матице}

У Бањалуци су прво са радом започеле Руска колонија и Руска матица, као два најважнија и најзначајнија удружења емиграната, која су била отварана и у свим другим центрима емиграције. У раду смо решили да поред кратких биографија њихових најпознатијих

16 Зоран Мачкић. Записи из Архива Републике Српске (9) - Украшавање палате Државне хипотекарне банке. 14.01.2013 10:00 (чланак на: http://www.glassrpske.com/plus/istorija/Zapisi-iz-Arhiva-Republike-Srpske-9-Ukrasavanje-palate-Drzavne-hipotekarne-banke/ lat/106054.html)

17 Зоран Мачкић. Записи из Архива Републике Српске (9) -Украшавање палате Државне хипотекарне банке. 14.01.2013 10:00 (чланак на: http://www.glassrpske.com/plus/istorija/Zapisi-iz-Arhiva-Republike-Srpske-9-Ukrasavanje-palate-Drzavne-hipotekarne-banke/ lat/106054.html) 
директора кажемо укратко нешто о њиховој делатности, која је имала значаја не само за емигранте, него и за локално становништво. Руска колонија активно делује у Бањалуци од 1924. године. Била је од највећег значаја за време владавине Независне Државе Хрватске. Многи њени чланови су успешно избегли регрутовање у усташке редове захваљујући томе што нису имали држављанство. Као посебан одсек руске колоније формирана је Национална младеж Руске колоније (НМРК). Колоније су одржавале ред међу емигрантима, бавиле се социјално - хуманитарном делатношћу колико је то било могуће имајући у виду средства, а имале су велику улогу и у запослењу. Културна делатност је такође била много значајна. Поред Руске колоније, једна од најзначајнијих организација током емиграције била је Руска матица. Основана је по узору на матице осталих словенских народа, које су одиграле кључну улогу у очувању и развоју њиховог националног идентитета. 18 Један од главних покровитеља Руске матице у Бањалуци био је први бан Врбаске бановине Светислав Тиса Милосављевић. У оквиру ове организације је постојала и библиотека са великим фондом руских и страних књига, часописима и периодиком. Посебно важну улогу су ова два удружења имала у обележавањима значајних за руску емиграцију датума и годишњица.

Виталиј Макарович Ромер-Рибкин, служио је од 24. октобра 1916. до 12. новембра 1920. у Руској војсци у чину потпоручника. Дипломирао је 26. јуна 1926. на Техничком факултету у Загребу, стекавши звање машинског инжењера. Исте године постављен је за контрактуалног асистента на Пољопривредно-шумарском факултету у Загребу. Оженио се 2 . јула 1926. године у Сарајеву са др Јекатерином Мурзом, кћерком др Александра Мурзе и Јелисавете Медведев. Виталиј Макарович је у априлу 1933. положио испит за овлашћеног машинског инжењера, а 5. децембра 1935. испит за асистента на Универзитету у Загребу. Од 4. маја 1936. у Загребу се бавио предузетништвом, а у Бањалуци је вршио послове овлашћеног инжењера. У Бањалуку се доселио 1937. и био једини машински

18 Тома Миленковић, Момчило Павловић. Белоемиграција у Југославији, Београд, 2006, стр.234. 
инжењер тада, а 17. октобра 1939. постављен је за суплента Државне средње техничке школе. У току рата Виталиј Макарович је био председник Удружења инжењера и техничара, а од јесени 1943. до јесени 1944. управник Државне техничке школе у Бањалуци. Са те дужности је смењен након истраге спроведене у Загребу на основу пријаве Усташког стожера у Бањалуци. У јесен 1942, након што је дошло до раскола у редовима руске омладине, а на препоруку Представништва руске емиграције у НДХ, инж. Виталију Макаровичу је поверено вођење Националне младежи Руске колоније, која је била огранак бањалучке Руске колоније. Већ трећег дана по уласку у Бањалуку, 25. априла 1945, О3Н-а је ухапсила Виталија Макаровича под оптужбом да је био «главни руководилац омладинске фашистичке организације НМРК (Националне младежи Руске колоније) у Бањалуци од прољећа 1942. до дефинитивног ослобођења града». Осуђен је на две године затвора. ${ }^{19}$ Априла 1945, у време док је против Виталија вођен политички процес, др Јекатерина је мобилисана у JHA и премештена у Сарајево, а затим у Загреб. Породици Рибкин је био уручен налог за исељење из стана у Улици Владимира Назора 6, са образложењем да ће се рушити зграда, која је била оштећена у току савезничког бомбардовања Бањалуке 29. маја 1944. Међутим, у стан је усељена друга породица, а сама зграда је порушена након земљотреса 1969. Свакако треба напоменути и да су Виталиј и Јекатерина у току рата усвојили српску дјевојчицу Ангелу (Анђелију) Трбојевић (1934-1997).

Василиј Михаилович Кашкаров, рођен 1863. године, био је вишегодишњи председник бањалучке подружнице Руске колоније, књижевник, публициста и потпуковник, члан Руског генеалошког друштва, Библиографског друштва при Московском универзитету и Археографске комисије, учесник Првог светског рата, грађанског рата и Бијелог покрета, начелник одељења за штампу Штаба главнокомандујућег Руске армије. Емигрирао 1920. у Краљевину СХС.. Умро је у Београду 27. јуна 1935. Да је оставио велики траг у Бањалуци, говори и чињеница да му је одржан парастос у Српској

19 о оптужбама подигнутим против Виталија Рибкина и Јевгенија Антониевича писао је Зоран Мачкић у свом тексту „Руска колонија у Бањалуци 1941-1945“ 
православној саборној цркви. ${ }^{20}$ Више детаља из његове биографије, нажалост, нисмо успели да пронађемо.

\section{4. Лекари}

Већина лекара која је радила у Бањалуци је већ завршила факултете у доревулуционарној Русији. Међутим, доста је оних чије је школовање било прекинуто немилим догађајима 1918. године, те су студије медицине завршавали у Београду или Загребу. Иако су многа документа изгубљена или настрадала у пожару, ипак су сачувани „Очевидник о лијечницима за подручје града Бањалука од 1. маја 1944.“ и „Попис лијекара за град Бањалука од 18. октобра 1944“, који су послужили као врло битни извори захваљујући којима приводимо поједине информације у овом делу рада.

Познато је да је Григориј Иванович Јелатанцев (1895-1988) ратовао у војсци П. Н. Врангела. Русију је напустио у новембру 1920. за време евакуације са Крима. Завршио је Медицински факултет у Београду 1930. Пре студија се издржавао физичким радом, продајом новина, као помоћник у књижари и радом у руднику у Зајечару. Након дипломирања је радио на Анатомском институту Медицинског факултета у Београду. Специјалистичке студије хирургије је морао да прекине због тешке финансијске ситуације и да се посвети општој пракси. Радио је као лекар у Српцу 1932-1936, бановински лекар Удружене здравствене општине Љубија 1936-1940, лекар Хигијенског завода у Бањалуци од 1940-1941. и срески лекар у Двору на Уни од 6. априла до ослобођења 1945. Тек му је у јуну 1950. године било враћено држављанство, захваљујући настојању Министарства здравства.

Оженио се 1925. године Олгом Константиновном Јелатанцев, стоматологом, која је обављала приватну праксу. Имали су два сина Ростислава и Виктора. Григориј је умро 10. децембра 1988, а Олга 5. октобра 1983. Сахрањени су на гробљу Мирошевац у Загребу. ${ }^{21}$ Након 40

20 Врбаске новине, 7.7.1935, стр. 2.

21 Руски лекари у Краљевини Срба, Хрвата и Словенаца/Југославији: Биографски речник и анкете (1918-1946). Београд - Москва 2012. стр. 102, 103, 104. 
година и 47 дана радног стажа, Григориј је пензионисан 6. марта 1967, а нешто пре тога преселио се у Загреб. Као пензионер је написао мемоаре под насловом «Билое», животопис својих родитеља, «Повијест Козака» и «Дивље поље», у којем је описао историју и природу своје домовине. Био је одликован Орденом заслуге за народ са сребреном звездом (1966). Добитник је Споменице Црвеног крста Југославије (1955) и Спомен-дипломе Сабора општине Јастребарско (1970). ${ }^{22}$

Семјон Иванович Максимов био је психијатар. Дипломирао на Медицинском факултету у Загребу 31. јануара 1940. Приватну лекарску праксу обављао је на основу одлуке Лијечничке коморе Загреб од 7. августа 1941, број 2.071/1941. Лекарску приправничку службу завршио је у Државној болници у Бањалуци 7. јула 1941. године, где је наставио да ради као волонтер. Здравствена сатнија Домобранске болнице у Бањалуци, под бројем 1398 од 30. новембра 1941. године, издала је потврду да је Семјон Максимов био на вежби код ове сатније од 29. августа до 30. новембра 1941. Државна болница у Бањалуци, актом 676 од 6. марта 1942. године, обавестила је Министарство здравства да за постављење Семјона Максимова има слободно место и отворене намере по прорачуну за 1942. годину. Министар здравства га је 30. априла 1942. именовао за здравственог вежбеника $X$ чиновног разреда код Државне болнице у Бањалуци. Венчао се 27. октобра 1931. са Маријом Барчевић. Његова бивша жена Елизабета Бајер рођена је у Будимпешти. Радио је као лекар примаријус у Душевној болници у Врапцу од 1933. до 1940, као лекар Државне болнице у Београду од 1940 до 1941. године, затим као лекар у Државној болници у Бањалуци од 1941. до 1943. Занимљива је чињеница да му је за време рада у Врапцу, Општинско поглаварство Врапче, срез загребачки, доделио 7. марта 1940. завичајност чиме је Семјон постао држављанин Краљевине Југославије. Молба за признавање држављанства обновљена је током 1949. и упућена Министарству унутрашњих послова НРБиХ.

Михаил Максимович Нагорни био је познат као војни лекар, санитетски мајор и специјалиста за кожне и венеричне болести (дерматовенеролог). Као активни санитетски капетан у Руској ратној

22 Зборник љечника Хрватске 1874-1974. Загреб 1974,. стр 425. 
морнарици је био од 1917. до краја 1920. године, затим је био мајор у ратној морнарици Краљевине Југославије од 1926. до 1938. године, када је премештен у копнену војску, где је остао све до 1941. године. Наравно, био је учесник Белог покрета од марта 1918. Као лекар је тада радио у Севастопољској војно-поморској болници. Евакуисан је заједно са војском генерала П. Н. Врангела на броду «Румјанцев» у новембру 1920. У емиграцији у Краљевини СХС се налазио од децембра 1920. Прво је радио као лекар у Војној болници у Мељинама 1921. године, затим као срески лекар од 1921. до 1926. у Санском Мосту, Доњем Лапцу, Пироту, Бољевцу и Подгори. Постављен је 1926. за санитетског поручника у Команди речне флотиле. Након тога је службовао на краљевском монитору «Драва» и у Речној обалској команди. Године 1930. је положио испит за санитетског капетана II класе. Лекарску специјализацију признала му је Дринска бановина решењем из 1931. На место управника Врбаске сталне војне болнице и референта санитета Врбаске дивизије био је постављен 1941. године, а већ 1943 је пензионисан као неподобан. На месту лекара у Државној болници у Бањалуци почео да ради 1. октобра 1943. Уговор му продужен 1. јануара 1944. У „Очевиднику о лијечницима за подручје града Бањалука од 1. маја 1944.“, редни број 24, дана 1. маја 1944. стављена је белешка да је без посла и да станује у Кватерниковој 20. у Бањалуци. Након ослобођења, од априла до августа 1945. радио је као помоћни хирург у Болници за лакше рањенике у Трапистима и као лекар по регрутацији код Команде среза Бањалука, а од 1945. као дерматовенеролог на Кожно-венеролошком оделу Окружне болнице Бањалука. У Окружној болници у Бањалуци једно време је вршио послове шефа Одељења за дерматолошко-венеролошке болести. У књигу држављана ГНО Бањалука уписан 22. октобра 1949. године, а становао је у Мартићевој 21. Писао је научне радове у струци од 1928, који су објављени у Војно-санитетском гласнику 1931. године. Те исте године изумео је прибор за узимање крви од људи, који је патентиран у Управи за заштиту индустријске својине у Београду. ${ }^{23}$ Умро у Сарајеву 14. августа 1973. У акту Персоналног реферата Извршног одбора СНО

23 тзв."Apparatus for blood taking in human". Медицински архив. Сарајево 1954. бр. 4. стр. 111-114 
Бањалука, број 568/47 од 5. јула 1947, наводе се карактеристике Михаила Нагорног: '>Према народно-ослободилачком покрету имао је потпуно шпекулантско држање, па и данас према НФЈ. Као стручњак је добар. Специјалиста је за дерматовенерологију. Према послу и странкама односи се потпуно бирократски. Према странкама је врло дрзак, а својим ласкањем воли своје грешке да поправи код претпостављених. Према задацима који су важни и неодложни не осећа се одговорним него на њих гледа површно и важно му је да за сваки свој корак на терену наплати дневнице иако задатак није уопште извршио. Због тих ствари неколико пута је позиван на одговорност, а ових дана је одговарао пред дисциплинским судом службеника. На дужности је референта за здравство при овом одбору на којој дужности уопште не задовољава...". Имао је врло леп глас, те је често наступао на приредбама Руске матице и Руске колоније. Говорио је француски и енглески језик.

Катарина Александровна Рибкин била је једна од оних која је завршила студије медицине у Загребу пре доласка у Бањалуку. Дипломирала је на Медицинском факултету 1928.године. Од 16. октобра 1929. до 23. септембра 1935. била је асистент-дневничар на Централном рендгенолошком институту Медицинског факултета у Загребу. Исте године положила је специјалистички испит и дошла у Бањалуку. Од 14. октобра 1935. до 1. маја 1937. радила је као уговорни лекар - рендгенолог у Подружници за осигурање радника у Бањалуци, а након тога је до 28. новембра 1942. била хонорарни рендгенолог у Државној болници у Бањалуци. Катарина је имала и своју ординацију у Бањалуци, о чему нам сведочи обавештење из Врбаских новина: „Мед. унив. др Катарина Рибкин отворила је своју ординацију. Врши све специјалне рендгенолошке прегледе и снимке плућа, зуба, костију и унутарњих органа. Ординира од 3-5 сваког радног дана или по претходном споразуму. Бања Лука. Пашићева 6.“24 Априла 1945. мобилисана је у Југословенску армију и премештена у Сарајево, а потом у Загреб. Пензионисана је 1945. у чину санитетског потпуковника. Написала је неколико научних и стручних радова. Умрла је 17. децембра 1995. у Загребу.

24 Врбаске новине, 20.08.1938. 


\section{5. Глумци и режисери}

Иако у Бањалуци није за стално боравио велики број глумаца, режисера, сценографа и костимографа ипак постоје имена која су оставила трага на бањалучким позоришним даскама. Њихово делање се углавном везују за 30-те и 40-те године. Неки од њих су само понекад гостовали у Бањалуци приликом обележавања важних датума за емиграцију, док су други активно и директно имали утицаја на бањалучку позоришну сцену, као што је то имао Александар Черепов.

Александар Филипович Черепов био је познати и цењени глумац, режисер и педагог. Пре револуције је као глумац дебитовао 1914. у Самари. Играо је у «Ермитажу» у трупама Мамонта Викторовича Даљског, Владимира Федоровича Лебедева и Александра Ивановича Јужина. После Октобарске револуције боравио је у више земаља (Немачка, Пољска, Аустрија, Чехословачка). Био је познат као изванредан рецитатор. У Риги је 1925. отворио своју позоришну школу, у којој је студенте учио по систему Станиславског. У Београд је дошао априла 1929. из Прага. У сезони 1938/39. и од јануара до априла 1941. радио је у Народном позоришту у Бањалуци, где је поставио Шоовог «Ђаволовог ученика», Голдонијеву «Мирандолину», Гогољевог «Ревизора» и Злочин и казну «Достојевског». Од априла 1941. био је режисер у Народном позоришту у Нишу, а 1941-43. директор трупе при Удружењу руских сценских радника. После ослобођења напустио је земљу и отишао у Немачку, где је 1946. године умро. „Решењем в.д. бана Врбаске бановине Гојка Ружића, за главног редитеља Народног позоришта краља Петра Првог Ослободиоца у Бањалуци постављен је Александар Черепов, познати позоришни радника из Београда. Ово је други пут како Черепов заузима положај главног редитеља Народног позоришта у Бањалуци. ${ }^{\text {"25 }}$

Ирина Петровна Астрова (Владивосток, 23. децембра 1909 - Шибеник, 1958) глумачку и певачку каријеру започела је 1929. у Београдској оперети, а потом је играла у Новом Саду (1930-31), Сарајеву (1931/32. и 1933/34), Скопљу (1934-36), Бањалуци (1936/37. и 1939-41), Осијеку (1937-39), Цетињу, Ријеци, Тузли, Задру и др. Највише успеха

25 Политика, 4.1.1941. 
имала је у певачким улогама, док јој је руски акценат у великој мери сметао да свој изразити глумачки сензибилитет испољи у потпуности у драмско-карактерном репертоару. На бањалучкој сцени остварила је запажене улоге у оперетама и комадима са певањем. Од 15. фебруара 1941. живела је и радила у Загребу, а од маја 1944. чланица је казалишне дружине X. корпуса HOBJ. Била је удата за новинара Ладислава Мелчицког. ${ }^{26}$ Завршила је 1927. руски Маријински донски институт у Белој Цркви и једно време студирала филозофију, музику и певање. Породица је дошла у Краљевину СХС маја 1920.

Поред Ирине у Бањалуци је још једна глумица остала запажена. Ираида Комаревска била је чланица путујућих позоришта и трупа. У бањалучком позоришту провела је сезону 1934-35. Удала се за Бориса Комаревског, диригента Ћирило-Методовог хора у Загребу, 1. октобра 1922. у Белој Цркви. Ираида је преко Немачке отишла у САД и тамо умрла у руском старачком дому.

Дриженко Јуриј рођен 1914. у Русији био је сценограф и костимограф, који је са породицом преко Цариграда и Ел Шата стигао 1920. у Југославију. Настанио се у Дубровнику, а потом у Руми. Једно време школовао се на Кадетском корпусу у Вршцу, затим је завршио Уметничку школу у Београду. Искуство је једно време стицао у сценографском атељеу Жедринског при Народном позоришту у Београду. Затим се уписао на Академију ликовних уметности, у класи Мила Милуновића. Будући да је био у тешкој финансијској ситуацији, као и многи припадници емиграције, решио је да оде у Бањалуку пред крај студија. У Бањалуци је био ангажован као сценографи костимограф 1940/41. После априлског слома усташе су га протерале из Бањалуке, накончега је отишао у Загреб код рођака. На позив Ферде Делака поново се вратио у Бањалуку, у којој је провео сезоне 1941-43. Био је ожењен Маријом Мањом Фигенвалд, глумицом, редитељком и преводиоцем (Загреб, 2.9.1913 - 6.9.1995), која је у Бањалуци радила 1941-42. и 194851. Након тога вратила се у Загреб и радила на загребачком радију. ${ }^{27}$ Његова кћерка Свјетлана Плазовић-Дриженко из Загреба поклонила је Народном позоришту и граду Бањалуци четири слике свог оца. 
«Све ове слике су везане за Бањалуку. Драго ми је што је град који је инспирирао мог оца прихватио његова дјела ${ }^{28}$, изјавила је Свјетлана Плазовић-Дриженко.

Бањалуку је посетио током 1934/35 године још један велики глумац и режисер - Александар Александрович Верешчагин. Повремено је наступао и као глумац, интерпретирајући углавном карактерне улоге. Несумњиво је дао врло значајан допринос модернизацији бањалучког позоришта. Важно је напоменути да је Вершчагин био запажени глумац петроградских позоришта В. Ф. Комисаржевске и Старинског позоришта Н. Н. Јеврејинова, ), После избијања револуције 1918. отишао је на Кавказ, где је кратко био директор Руског позоришта. Одатле, пут га је преко Цариграда, Софије, Атине и Солуна довео у Краљевину СХС. Био је ангажован у Београду (1919-20), Скопљу (1920/21), Сарајеву (1921/22), Сплиту (1922), Загребу (1923/24), Новом Саду (1931-1944). У Загребу је радио и као наставник на Државној глумачкој школи, где је увежбавао комаде Чехова и Молијера. У Новом Саду је једно време био и уметнички руководилац Српског народног позоришта. Режијом и глумом у драми „Васа Железнова“ овде је 1938. године обележио 35. годишњицу свог уметничког рада.

\section{6. Професори и учитељи}

Бањалукаје помак уобразовном системудоживела тек доласком бана Светислава Милосављевића 1929. године. Тада је отворене Нижа пољопривредна школа, а Учитељска школа је премештена из Дервенте у Бањалуку. Изграђена је и отворена Реална гимназија, која је нажалост настрадала током потреса 1969.године. Стање просвете се побољшало када су основане: Женска гимназија, Трговачка академија и Занатске школе. Сви већи центри руске емиграције су иначе отварали руске образовне установе, међутим у Бањалуци, која је тек градила темеље свог образовног система и културе, није било услова за то. Квалитету образовања утадашњој Бањалуци су засигурно

28 Независне новине, 4.6.2008. 
допринели многи руски емигранти који су радили као професори или учитељи. Они који су успели у својој домовини завршити образовање нострификовали су своје дипломе, остали су полагали стручне испите у Загребу и Београду као већим центрима емиграције КСХС. Били су у тешком положају и често су премештана из једног у други град, о чему сведоче биографије многих професора, док смо се у овом раду ограничили само на неке од њих.

Засигурно једна од најзначајних личности руске емиграције у Бањалуци био је професор Владимир Курагин. Био је диригент мешовитог хора Учитељске школе 1929, а школске 1928/29. предавао је певање на Гимназији. Утоку 1927. године радиоје као контрактуални учитељ вештина на Државној крајишкој учитељској школи у Бањалуци. На основу одобрења Умјетничког одјељења Министарства просвјете, 4465 од 28. новембра 1927. године, велики жупан Врбаске области одобрио му 5. јануара 1928. под бројем 120/28 оснивање музичке школе (студија) са седиштем у Бањалуци (Гундулићева улица бр.26). „Студија има задаћу: Да даде могућност сваком, а особито школ. деци за кратко време и са малим матер. жртвама да прођу озбиљну школу у оној грани уметности, за коју има особити дар; 2) да његује музику домаћу и страну, која ће правилно и корисно утицати на оплемењивање дечије душе; 3) да теоријском и практичном наставом спрема наставнике певања и свирања за средње школе." У склопу студије постојала је и музичка библиотека која је била на располагању свим ученицима. Како многи нису поседовали инструменте, студија се побринула и за то, па је ученицима било дозвољено да се служе школским инструментима. Будући да је тај период био финансијски тежак не само емигрантима, већ и самим Бањалучанима, школа је имала и три бесплатна места за сиромашне ученике.

Наталија Анциферова завршила је 1920. двогодишњи педагошки курс. Допунски учитељски испит положила 1926. у Београду. Удала се 1931. за трговца Тихона Анциферова из Жабара, срез моравски. Из њене биографије сазнајемо да је често мењала место рада и школе. За учитељицу у Чоки постављена је 19. фебруара 1922, а пре тога је радила као надзорница Дома сирочади у Старој Кањижи. Као учитељица је даље радила у Ђали од 22. септембра 1924. године, 
затим од 4. октобра 1925. у Кисачу, од 12. јануара 1926. у Селенчи, а од 12. јануара 1929. у Станишићу. Познато је још да је радила и у Хадровцима код Санског Моста у периоду од 1933. године до 1936. године. «Ради са пуно љубави и воли свој позив. Ради веома живо и окретно, тактична у примењивању дисциплинских средстава, досљедна у раду и говору. У сталном је контакту са сељанкама и држи им предавања из домаћинства и ручног рада. Школски врт прописно обрађен и служи за углед. Воће одгаја веома лепо. Наставница је Рускиња али потпуно влада државним језиком, и ради веома лепо ${ }^{29}$. У Бањалуци је радила од 8. децембра 1945. до 16. децембра 1955. године, када је пензионисана. Из архивске грађе смо сазазнали да је остала удовица и да је имала дете од 15 година. Умрла је 1983. године у Бањалуци, где је сахрањена на Новом гробљу.

Владимир Федорович Богословски, завршио је Кадетски корпус 1917. године у Полтави, а филозофски факултет 1926. године у Београду. Положио је професорски испит у Београду у априлу 1929. Од 1. септембра 1925. до почетка фебруара 1930. године, са прекидима, службовао је као контрактуални привремени предметни учитељ, контрактуални суплент и контрактуални професор гимназије у Бањалуци. Дана 7. фебруара 1930. постављен је за контрактуалног професора Мушке реалне гимназије у Нишу. Премештен је 1931. године на Реалну гимназију у Вршцу, а затим на учитељску школу . У Бањалуку се вратио 1. септембра 1938. године и запослио на Женској реалној гимназији. Једно време је био и професор математике и физике на Државној мушкој реалној гимназији у Бањалуци, али 23. јануара 1942. године премештен на своју редовну дужност у Државну женску реалну гимназију. На бањалучкој гимназији предавао је све до 1970. године, када је пензионисан. Са супругом Драгом, која је 1945-55. такође предавала на бањалучкој гимназији, 27. јуна 1934. стекао је сина Александра. Умро је у Бањалуци.

Александар Давидов је један од ретких професора који су радили у Бањалуци, а који је успео завршити школовање у домовини. Завршио је Филозофски и Физичко-математички факултет. Из наставничко листа од 12. јула 1934. године сазнајемо да «оцењује

29 школски записник вероватно настао за време њеног рада у Хадровцима 
врло благо и једноставно даје тројке, те не може да одржи ауторитет на достојној висини. Не зна добро наш језик, те му и то смета успеху у настави». У Гимназији у Бањалуци предавао је математику и хемију, а радио је и у Нижој женској гимназија од 7. фебруара 1930. Уговор му је продужен за годину дана 25. октобра 1937. Одлуком Управе полиције у Бањалуци од 6.7.1939 . године продужен му је боравак до 12.6.1940. Уз одлуку је припојен лист са личним подацима, у којем стоји да је трговачки путник, бивши професор гимназије. По завршетку рата са супругом је живео у Бањалуци (Пашићева - Назорова 11), а радио у ближој околини Бањалуке. По одласку у пензију са супругом и унукама придружио се кћерки у Сарајеву.

«Својом дидактичко-методичком способношћу постиже у својој струци лепе успехе. Према ученицима поступа са врло много такта, те га ученици воле. Врло је марљив и реван. Оцењује правилно и тим стиче љубав и поштовање. Педантан је у свему што му се повери.» ово су речи којима је описан рад Алексеја Тимофејевича Фирсова у наставничком листу. Пре емиграције је одслушао 10 семестара на Физичко-математичком факултету, али је школовање наставио у емиграцији на Филозофском факултету у Загребу. Положио је професорски испит 1929. године у Загребу. Предавао хемију и природне науке. На бањалучкој гимназији радио је од 1952. до 1965. године. Новембра 1938. био је изабран за благајника шаховског клуба у Бихаћу. Умро 1983. у Бањалуци.

Борис Петрович Качалов био је руски коњички потпуковник. У КСXС је дошао 14. новембра 1920. године. Живео је у Тузли и успео стећи држављанство 1926. године. Основну школу завршио у Женеви, Пажевски кадетски корпус 1900. у Санкт Петрербугу. Испит спремности положио у Сарајеву, а дипломирао на Вишој педагошкој академији у Загребу. Говорио је француски, руски, њемачки и пољски. Као професор је предавао француски, географију и историју. Радо је као хонорарни наставник француског језика у Тузли од 28. августа 1921. Од 1928. године предавао је на Грађанској школи у Бањалуци, а од 1929. године у Гимназији. Након Бањалуке радио је у Лозници и Тузли. Умро је 20. августа 1942. 


\section{7. Закључак}

Бањалука је између два рата пролазила кроз велики преображај, те није представљала најидеалније место за живот нити први избор руским емигрантима. Број руских емиграната у односу на укупан број становника није био велик, али су и у тако малом броју многи од њих учествовали у научном, културном, уметничком и друштвеном животу града Бањалуке. Управо је то и био критериј по којем смо издвојили поједине емигранте захваљујући писаним траговима које смо пронашли.

Кроз рад смо се упознали са неким од најважнијих грађевина које су иза себе оставила велика имена попут Николе Фјодрова, Зелинског, Загородњука. Управо је њихов долазак у град означио стварање архитектонске сцене која до тада није постојала.Током емиграције ван Русије се развио велики број различитих организација. У раду смо кратко представилирадРускеколонијеиРускематицекаоосновнихорганизација саме емиграције. За свако истраживање ове врсте важни су и трагови постојања друштвеног живота. Иако нам то није био фокус у овом раду, кроз биографије многих емиграната смо имали прилику видети да је био прилично богат. На основу чињенице да су чланови руских организација често били и сами Бањалучани, а и обрнуто можемо закључити да су са временом без већих препрека могли да коегзистирају. Сваке године је био организован помен руском цару Николају и обележавао се један од најважнијих датума у руској емиграцији „Пушкинова прослава“. Неретко су биле организоване књижевени вечери, представе и концерти. У прилог блискости две заједнице иде и поменута прича породице Рибкин о усвајању девојчице.

У Бањалуци не постоји неко од старијих генерација који не може поделити бар једну анегдоту о „професору Русу“. Кроз рад можемо приметити да су у биографијама поједине судбине емиграната, и судбине њихових породица понекад непотпуне. Поуздано знамо да је велики број емиграната који су боравили у Бањалуци отишао даље за Загреб, где су имали боље услове за рад и напредак. Но будући да су се и тамо ретко задржавали, тешко је у потпуности испратити њихова даља кретања. Поред емиграната из Русије, у Бањалуци је било доста емиграната и из Украјине. О њима такође постоји доста материјала у архиву Републике Српске, те се даљим радом планирамо осврнути и на њихове судбине. 


\section{Извори}

Архивска грађа:

Архив Републике Српске

Штампа и периодика:

Врбаске новине

Политика

Службени војни лист 1398-1920

\section{Интернет:}

Храм Христа Спасистеља званична интеренет страница http://hhsbl.org/index. php?option=com_content\&view=article\&id=5\&ltemid=5\&lang=sr\&limitstart=3 (04.12.2015.)

Зоран Мачкић. Украшавање палате Државне хипотекарне банке. http://www. glassrpske.com/plus/istorija/Zapisi-iz-Arhiva-Republike-Srpske-9-Ukrasavanjepalate-Drzavne-hipotekarne-banke/lat/106054.html (05.08.2015.)

Зоран Мачкић. Устав Руске матице у Бањалуци. http://www.zoranmackic.com/index. php/2010/09/ustav-ruske-matice-u-banjaluci (10.05.2015.)

Зоран Мачкић. Записи из архива:Изградња палата Банске управе и Банских двора: Двије несуђене скице.

http://banskidvor.org/zapisi-iz-arhiva-izgradnja-palata-banske-uprave-i-banskih-dvoradvije-nesudjene-skice/ (26.11.2016.)

Зоран Мачкић. Бањалучки Руси. http://www.glassrpske.com/plus/istorija/BanjaluckiRusi/lat/111960.html (12.07.2015)

\section{Остало:}

Именик дипломираних инжењера и архитеката на Техничком факултету Универзитета у Београду 1919-1938

Руски лекари у Краљевини Срба, Хрвата и Словенаца/Југославији: Биографски речник и анкете (1918-1946). Београд - Москва 2012.

Зборник љечника Хрватске 1874-1974. Загреб 1974

\section{Подаци из Архива за ликовне умјетности}

Хрватске академије знаности и умјетности:

Бранко Хећимовић.Репертоар Хрватских казалишта.Загреб 1990.

Магдалена Медарић. Допринос руских емиграната хрватској ликовној култури сликарству, кипарству, архитектури, фотографији и филму. Загреб 2004.

Библиографија расправа и чланака. Казалиште у Хрватској и Босни и Херцеговини, 1826 - 1945. св. І. и II. Загреб. Хрватски Лексикографски Завод, 2004 


\section{Литература}

Алексеј Борисович Арсењев. Русская эмиграция в Боснии и Герцеговине. Ежегодник 2011 Дома русского зарубежья им. А.Солженицына. Москва. 2011

Исидора Церовац. Руска емиграција у Бањалуци. Београд. 2016. (мастер рад)

Татјана Пушкадија-Рибкин. Емигранти из Русије. Загреб. 2006.

Зоран Мачкић. Руска колонија у Бањалуци 1941-1945. „Гласник Удружења архивских радника Републике Српске“ број 4. Бањалука 2012.

Тома Миленковић. Момчило Павловић. Белоемиграција у Југославији. Београд. 2006.

\section{Isidora Cerovac}

\section{KNOWN RUSSIAN EMIGRANTS IN BANJA LUKA(1925-1945)}

\section{Summary}

This paper deals with the research of the life and work of well-known Russian emigrants, who stayed and worked in Banja Luka in the framework period from 1925. until 1945. In our work we limited ourselves to several professions, including architects, directors of important emigrant associations, doctors, teachers and professors, directors and actors.

The research was primarily done on the basis of archival material kept in the Archives of Republika Srpska in Banja Luka. Most of the materials are of an electronic type, and for many documents we do not have the exact classification according to which they are stored in the archive. With the topic of Russian emigration in Bosnia and Herzegovina almost nobody dealt with. Concerning the life and work of the Russian community in Banja Luka, only Zoran Mačkić wrote. He published several articles in the newspapers "Journal of the Association of Archival Workers of Republika Srpska" („Glasnik Udruženja arhivskih radnika Republike Srpske").

By analyzing archival material and a few texts, the author of the paper tried to bring a picture a picture of life and work only of some of the most prominent Russian emigrantsin the former center of Vrbas Banovina.

Keywords: Russian emigration in Banja Luka, archivematerial, Russian Colony, Russian Matica, Russian intelligence, architects, doctors, teachers and professors, actors and directors. 